\title{
Socio-Economic Impacts of Tourism Development in Rural Area of Sembalun East Lombok West Nusa Tenggara
}

\author{
CH. Dian Vitriani ${ }^{*}$, Djoko Sudibyo ${ }^{2}$, Henky Hermantoro ${ }^{3}$ \\ 1,2,3 Sekolah Tinggi Pariwisata Trisakti \\ *dian_vitriani@yahoo.com
}

\begin{abstract}
Tourism development brings both positive and negative social, economic and environmental impacts, and so does the development of rural tourism in Sembalun. Tourism is considered to have a great potential to improve people's welfare. The Sustainable Livelihood Framework is an instrument used to analyse the socio-economic impact of tourism development on the livelihood of local communities in Sembalun. This research is a replication of previous research in 2010 in Borobudur. This research compares the results of the impact analysis of heritage tourism in Borobudur with rural tourism in Sembalun on community livelihood based on the Sustainable Livelihood Framework instrument, not based on its different tourism attractions. In Sembalun the agricultural and tourism sectors support each other. The tourism sector has also proven to bring positive socio-economic impacts to local communities, such as promoting Micro, Small and Medium Enterprises (MSMEs) products, increasing training and financial supports, job creation, cultural preservation, and pride and feeling of becoming part of the tourism development in their village. Tourism is also considered to have a positive impact in improving people's welfare. The most commonly complained negative impacts are waste as well as concerns that the local culture will be eroded by foreign culture brought by tourists.
\end{abstract}

Keywords: tourism impact, sustainable livelihood framework, sustainable tourism, community based tourism, rural tourism

TRJ Tourism Research Journal, Volume 1 (1), 2017 


\section{A. Introduction}

A strategic role of the tourism sector in creating added value for the national economy is proven. Travel \& Tourism continued to show its resilience in contributing direct GDP growth of $3.1 \%$ and supporting 6 million net additional jobs in the sector in spite of the ever-increasing and unpredictable shocks from terrorist attacks and political instability, to health pandemics and natural disasters.(WTTC:2017). In total, Travel \& Tourism generated US\$ 7.6 trillion (10.2\% of global GDP) and 292 million jobs in 2016, equivalent to 1 in 10 jobs in the global economy. The sector accounted for $6.6 \%$ of total global exports and almost 30\% of total global service export. The outlook for the Travel \& Tourism sector in 2017 remains robust and will continue to be at the forefront of wealth and employment creation in the global economy, in spite of the emergence of a number of challenging headwind.

The Medium-Term Development Planning of Indonesia (2014-2019) has identified tourism as one of the main development sectors. It is estimated that in 2017, tourism will contribute 13\% to National GDP with expected number of foreign tourists of 15 million and local tourists 265 million. It is also projected that in year 2020, tourism sector will be the main earnings for Indonesia foreign exchange. The tourism sector is an effective sector in addressing the need to increase economic added value in tackling poverty (pro-poor) and job creation (projob). In addition, the tourism sector also contributes to the realisation of the Indonesia's National Development Priority, namely creating harmony between welfare and justice along with environmental protection as outlined in the concept of pro-growth, pro job, pro-poor and pro environment.

The concept of rural tourism is believed to be a new solution for tourism development. It happens in response to a shift in tourist's interests. Conventional tourism products are becoming forsaken and tourists are turning to tourism products that in particular value the environment, nature and culture. The satisfaction of tourists no longer rely on the natural beauty and completeness of tourist facilities but also on the flexibility and intensity of interactions with the environment and local communities. The developed tourist packages are based on these rural resources and on locality, such as homestays (Susyanti, 2013, Hermantoro, 2014).

In addition, the village also has a strategic role in the national development because it supplies almost all food needs nationwide. Unfortunately, at this time the village itself has not been in accordance with its important role. In the year 2016 the poverty rate in rural areas is 17.3 million people while in urban areas 10.5 million people (BPS, 2016). Currently many of the existing workforce are no longer interested in working in rural areas because the agricultural sector is deemed unable to provide sufficient income for them compared to income people get in industry and trade sectors in urban areas. As a result, a significant number of people has migrated from village to city. Between 
2015 and 2016 the agricultural workforce is reduced by 1.8 million people (BPS, 2016).

Unlike the other sectors, the tourism sector is the right choice for improving the welfare of rural people because this sector is able to provide economic added value to the existing rural resources, not replacing the function of the resources. The approach should be more focused to empower the rural community in building their own village and not to be dependent to the external supports. This emphasis is very important because many practices of tourism development actually weaken the local communities due to the entry of external actors who come with big capital in a massive way. In contrary to local communities, for those big investors, the economic mission is far more important than the mission to build the village in the long-term.

Sembalun Sub-district (kecamatan) located in East Lombok Regency (kabupaten) has huge tourism potentials, including one as a gateway to Mount Rinjani National Park. East Lombok regency is the widest regency in Lombok Island with an area of up to $1.605,55 \mathrm{~km}^{2}$ or equal to $33,88 \%$ of Lombok Island reaching $4.738,7 \mathrm{~km}$ with the smallest population density and is the only subdistrict in NTB with the density below 100.

Sembalun has a cool temperature with a height of $800 \mathrm{mdpl}-1.250 \mathrm{mdpl}$ and an area of $217,08 \mathrm{~km}^{2}$ which includes six villages, namely Sembalun Bumbung Village, Sembalun Lawang Village, Sajang Village, Bilok Petung Village, Sembalun Village, and Sembalun Timba Gading Village. By 2015 the population of Sembalun sub-district is 19.743 people, with $52 \%$ female and $48 \%$ male. The age group of the majority of residents in Sembalun Sub-district is in the age range of $0-19$ years, thus in the next 15 years this group will be in the productive age group. The livelihood of the residents in Sembalun Sub-district is mostly in the agricultural sector, either as farmers with land or as farm laborers (BPS Kecamatan Sembalun, 2015). This is also in accordance with the data as stated by BPS of East Lombok (2016), that in 2015 most of the workforce is absorbed by the agricultural sector, employment in this sector is around $45,65 \%$. Furthermore, the trade, restaurant and accommodation sectors are around $17,90 \%$, while the manufacturing and services sectors account for $11,16 \%$ and $13,87 \%$ of the workforce respectively.

As an area of volcanic eruption, horticultural agriculture in Sembalun also thrives. Sembalun is well suited as a farming area. The existence of agricultural land in Sembalun is seen as a special attraction for visitors and farmers grasp it as a business opportunity in agrotourism. In the tour packages offered, the tourists are invited to participate in farming activities. This is also supported by a large potential market. During the last five years within the period of 2011-2015, the number of tourist arrivals in Mount Rinjani National Park (TNGR) continues to increase significantly. 
Table 1. Number of Tourist Arrivals of Mount Rinjani National Park 2011-2015

\begin{tabular}{lccccc}
\hline & 2011 & 2012 & 2013 & 2014 & 2015 \\
\hline Number of tourists (persons) & 15.030 & 19.782 & 37.838 & 61.692 & 70.705 \\
percentage of increase (\%) & 7,70 & 31,62 & 91,27 & 63,04 & 14,61 \\
International tourists (persons) & 8.778 & 10.956 & 17.634 & 24.176 & 27.186 \\
Domestic tourists (persons) & 6.252 & 8.826 & 20.204 & 37.516 & 43.519 \\
\hline
\end{tabular}

Source: Statistik Balai Taman Nasional Gunung Rinjani 2015, page 78

In his research, Yanuar et al (2014) stated that more than half of tourist arrivals visiting Mount Rinjani National Park pass through and visit Sembalun. The following is the increasing of tourist arrivals to Sembalun for the period of 2006-2015.

Table 2. Number of Tourist Arrivals in Sembalun 2006-2015

\begin{tabular}{rrrrrr}
\hline Year & $\begin{array}{c}\text { Domestic } \\
\text { tourists }\end{array}$ & $\begin{array}{c}\text { Percentage of } \\
\text { domestic } \\
\text { tourists }\end{array}$ & $\begin{array}{c}\text { International } \\
\text { tourists }\end{array}$ & $\begin{array}{c}\text { Percentage of } \\
\text { international } \\
\text { tourists }\end{array}$ & Total \\
\hline 2006 & 1.721 & $54 \%$ & 1.469 & $46 \%$ & 3.190 \\
2007 & 2.208 & $61 \%$ & 1.427 & $39 \%$ & 3.635 \\
2008 & 3.390 & $65 \%$ & 1.827 & $35 \%$ & 5.217 \\
2009 & 1.481 & $55 \%$ & 1.210 & $45 \%$ & 2.691 \\
2010 & 4.876 & $71 \%$ & 1.952 & $29 \%$ & 6.828 \\
2011 & 4.223 & $54 \%$ & 3.668 & $46 \%$ & 7.891 \\
2012 & 4.391 & $49 \%$ & 4.593 & $51 \%$ & 8.984 \\
2013 & 8.612 & $52 \%$ & 7.974 & $48 \%$ & 16.586 \\
2014 & 12.663 & $37 \%$ & 21.739 & $63 \%$ & 34.402 \\
2015 & 18.517 & $40 \%$ & 27.663 & $60 \%$ & 46.180 \\
\hline
\end{tabular}

Source: Statistik Balai Taman Nasional Gunung Rinjani 2015, page 81

The concept of rural tourism is also considered to be able to improve the local economy more equitably. But on the other hand, as more tourists visit Sembalun, there is a concern that tourism activities tend to exploit existing resources. The purpose of building a tourist village is then no longer for the welfare of the community and the preservation of the village environment but only to pursue the number of tourist arrivals. As a result, many rural tourism attractions are damaged by the forms of mass tourism and this will damage the long-term rural resources (Buku Panduan Pengembangan Desa Wisata Hijau, 2015).

The growth of tourist numbers will indeed directly affect the environmental carrying capacity. But more than that, the moral influence, ethics and lifestyles of both tourists and local communities actually become the main problems for the environmental carrying capacity. Even with relatively small numbers, the lifestyles of tourists and local communities which are not enviromentally friendly, such as littering and wasteful use of resources, are the main cause of environmental damage. Moreover, tourists may also contribute to 
socio-cultural damage to local communities when foreign cultures are forced into local cultures as the local communities are not ready to receive them. On the other hand, the tourism industry and the local communities can contribute to the destruction of tourism destinations in many ways, including the structure of the local economy when the large capital cannot accommodate or even displace local businesses (Hermantoro, 2015).

Palomino (2003) stated that many countries see tourism as a major source of foreign exchange and a solution to ease the economic crisis with foreign capital injection. Nevertheless, tourism does not always lead to positive results. Several studies have revealed the negative impacts of tourism from physical impacts such as environmental degradation, resource depletion and pollution, to socio-cultural impacts such as unfair distribution of income and increased use of drugs, crime, and so on. Many articles indicate potential tourism impacts that damage tourism to the society, culture and environment.

There are serious risks that as tourism expands rapidly, local communities will rapidly develop tourism destinations without sufficient planning, management and local capacity building. This is likely to lead to problems such as pollution, noise pollution, poor waste management, resource scarcity, community conflict and exploitation of local community members (Thailand Community Based Tourism Institute, 2013).

The tourism sector is an important economic activity in most countries around the world. As well as its direct economic impact, the industry has significant indirect and induced impacts on three main aspects of development (triple bottom line) covering economic, social-culture and environment. Sustainable tourism development is an effort to maximise positive impacts and minimise the negative impacts of tourism activities on these three aspects of development, and to pay attention to the needs of the environment, local communities, and the tourism industry itself for both current and future life. Hermantoro (2015) stated that various terms of development approach then appear and often used interchangeably, but do not have exactly the same understanding. Two terms that are often used to explain the above are responsible tourism and sustainable tourism.

This research focuses on socio-economic impacts, which are two types of impacts that are often coherent and difficult to differentiate. According to Kausar (2010), socio-economic impacts can be defined as changes in social structures influenced by economic impacts. Based on the above-mentioned background and considering the literature review of approaches related to rural tourism development, the research questions that this research set out to answer are as follows: "What impacts have resulted from the development of Tourism in Rural Area of Sembalun? What factors affect the generation of these impact?

Tourism impacts, according to Ritchie and Goeldner (1994) and Mason (2003) in Kausar (2010), include economic, social, and environmental impacts. 
Socio-Economic Impacts of Tourism Development in Rural Area of Sembalun East Lombok West Nusa

This research focuses on social and economic impacts, two types of impacts that are often intertwined and difficult to differentiate, hence the term socioeconomic impacts.

In this research the scope is limited to the social and economic aspects of the impacts of tourism development in Sembalun on the livelihoods of its people. In addition, the research also discusses the approaches related to rural tourism development, i.e. sustainable tourism development, community-based tourism, including Micro, Small and Medium Enterprises (MSMEs) and women's involvement in tourism activities.

\section{B. Literature Review}

1. Previous Researches

The two previous researches, namely the case studies of the development of conservation-based rural tourism in Namibia (Ashley, 2000) as well as the development of heritage tourism in Borobudur, Indonesia (Kausar, 2010), serve as the references in replicating the Sustainable Livelihood Framework instrument as an analysis tool for the development of rural tourism in Sembalun East Lombok NTB. This research compares the results of the impact analysis of heritage tourism in Borobudur with rural tourism in Sembalun on community livelihood based on the Sustainable Livelihood Framework instrument, hence not based on its different tourism attractions.

\section{Sustainable Tourism}

According to the World Commission on Environment and Development (WCED), sustainable development defines as "meets the needs of the present without compromising the ability of future generations to meet their own needs" (WCED, 1987). From here, the concept of sustainable tourism is created. The term "sustainable tourism" comes from the general concept of "sustainable development". The World Tourism Organization (UNWTO) defines sustainable tourism development as follows: "Tourism that takes full account of its current and future economic, social and environmental impacts, addressing the needs of visitors, the industry, the environment and host communities".

Management practices and guidelines for sustainable tourism development can be applied to all forms of tourism activities in all types of tourism destinations, including mass tourism and other types of tourism activities. The principles of sustainability refer to the economic, socio-cultural and environmental aspects of a tourist destination. To ensure long-term sustainability, the balance between these three dimensions must be wellestablished.

Sustainable tourism development requires the participation of relevant stakeholders and strong political leadership in order to ensure active participation and agreement among stakeholders. Achieving sustainable tourism 
is a continuous process and requires constant monitoring. Innovation of prevention and mitigation measures required for the impacts of tourism activities should be continued as well.

Sustainable tourism development is a long-term approach that cultivates economically viable tourism without harming residents' environment or society while simultaneously ensuring fair distribution of costs and benefits (DBEDT, 2006). Decisions are based on economic, environmental, and cultural impacts; how wealth is generated and distributed; and the relative power and interactions among the stakeholders (Bramwell, 2006; Twining-Ward \& Butler, 2002 in Assante et al., 2007). Sustainable tourism development balances industry's goal of profit with the needs of the environment and stakeholders (Bramwell, 2006 in Assante et al., 2007). Stakeholder cooperation is necessary for sustainable tourism; otherwise only the most powerful will benefit (Dyer, Gursoy, Sharma, \& Carter, 2007 in Assante et al., 2007).

\section{Community-Based Tourism}

Community-Based Tourism (CBT) is a tourism that is generally held on a small-scale where there are interactions between visitors and the host communities. CBT is a form of tourism that promotes ownership and active participation of the community, educates local people and visitors, promotes protection to culture and the environment, and economic benefits to local communities.

CBT is usually better suited to rural areas, managed and owned by local communities and for local communities, by promoting local tourism providers and focusing on culture and the environment as its attraction (Asker et al., 2010). Another definition stated that CBT aims to promote the participation and ownership of local communities towards tourism developed in their region (UNWTO STEP Foundation, 2011). Hausler and Strasdas (2003) stated that CBT is a type of tourism whose development and management is controlled by local communities, where most of the benefits generated by tourism are enjoyed by local communities who are both directly and indirectly involved in tourism, and which provides education for visitors and local communities on the importance of conservation efforts on nature and culture.

CBT is often recognised as a perfect example of sustainable tourism development. The reason for this is mainly that local community participation in the development and practice of these projects is supposed to be high, and that the whole communities benefit from the projects (Brohman, 1996; Hatton, 1999 in van Breugel, 2013). Community development is at the heart of CBT. Most CBT projects are small scale and they often include community owned and operated lodges and other facilities. This would provide positive economic benefits, such as income for large parts of the community. Besides that, CBT is regarded as being less harmful to the socio-cultural environment. Because the 
local population is in control, they decide which cultural traits they share with their guests. Finally, CBT projects would also have less negative impacts on the natural environment. Community members are often the best to judge what is best for their natural surroundings. The small-scale character of CBT also means that small amounts of tourists are visiting and therefore do not cause overcrowding of the socio-cultural and natural environment.

\section{Promoting MSMEs and Local Products}

According to the Presidential Decree No. 99 year 1998, small enterprise defines as small-scale economic activity of the people that mostly is small business activities and need to be protected in order to prevent it from unfair business competitions. The definition of Micro, Small and Medium Enterprises (MSMEs) can be seen from various aspects, both in terms of capital owned by business actors, the number of labor they have or in terms of sales/turnover of MSME actors.

In general, the characteristics of MSMEs are stand-alone management, self-provided capital, local marketing area, small company assets, and limited number of employees. Saputra \& Rindrasih (2012) explained that the contribution of tourism to economic development at local and local level is caused by its multiplier effect on other sectors. Tourism provides an opportunity to build a business that will ultimately benefit a destination and its people. Ideally, the development of tourism destinations should be able to facilitate the growth of small, medium and large businesses in a region.

MSMEs have a strong influence on the economies of all countries, especially in an increasingly competitive global market (Ghibadian \& Gallear, 1996; Ladzani \& Van Vuuren, 2002 in Saputra \& Rindrasih, 2012). MSMEs contribute significantly to job creation, social stability and economic well-being (Ghibadian \& Gallear, 1996; Ladzani \& Van Vuuren, 2002; Steiner \& Solem, 1988 in Saputra \& Rindrasih, 2012). Utilising local products in developing rural industries (for consumption in the tourists'market) is actually one of the keys in establishing better linkages to tourism and a key for more widespread benefits of tourism (Greffe 1994; Hampton 2005; Boccardi et al. 2006 in Kausar, 2010).

\section{Engaging Women in the Tourism Management}

In its publication "Indonesia Labor Market Outlook", the ILO (2016) stated that in Indonesia women tend to earn lower wages compared to men in the labor market. Looking at labor market indicators established by the ILO, women are still far behind. Women's labor participation was 50.9\% (February 2015) and 52.1\% (February 2016), lower than most other surrounding countries. In fact, the gap of labor-participation rate between men and women is $33 \%$. The wage gap between men and women is still an issue. According to data in February 2016, women on average earn 78\% less income than their male colleagues (Rp 2.3 million for men vs Rp 1.8 million for women). 
UNWTO (2011) explains that empowering women to participate in economic development at all levels and sectors is essential to build a strong economy and a stable and just society. Tourism provides significant opportunities for women and men. Tourism can also help poor women to break the cycle of poverty through formal and informal work, entrepreneurship, training, and community improvement. However, not all women benefit equally from tourism development. In some cases, lack of education and resources hinder poor women from benefiting from tourism development. While in some destinations, tourism helps to empower women, but in other areas tourism negatively affects women's lives and perpetuates economic and gender inequalities.

\section{Tourism Impacts}

Inskeep (1991) stated that there are positive and negative economic and socio-cultural impacts as a result of tourism depending on the type and intensity of the tourism developed, as well as from the characteristics of the local communities. Whether the impact is perceived as positive or negative depends partly on the objective criteria, such as income received but also related to the perception of local communities, in which there are community groups that have different reactions to tourism development and often they cannot agree on a shared consensus.

Impact is a change (environmental, economic and social change) in a given circumstance and time as a result of external stimulus (Hall \& Lew, 2009). According to Ritchie \& Goeldner (1994) and Mason (2003), tourism impacts include economic, social and environmental impacts. In tourism, the impact of tourism is experienced by all elements in the "tourism system". The tourism system refers to various sectors involved in facilitating travel to and from a destination, and the interconnection between the sectors (Hall, 2008). There are several approaches for analysing the tourism system, such as from geographical point of view, supply and demand dimensions, and approaches that emphasise system functioning for specific stakeholder groups

According to Frechtling (1994) in Kausar (2010), studying the economic impact of tourism means analysing travel's activity impact on resident wealth or income in a defined area. Stynes (1997) in Kausar (2010), on the other hand, said that economic impact analysis of tourism traces the flows of spending associated with tourism activity in a region to identify changes in sales, tax, revenues, income and jobs due to tourism activity. Frechtling (1994) in Kausar (2010) acknowledged that many studies of tourism's economic impact emphasise on travel spending. However, Frechtling stresses that travel expenditure studies tend to obscure the impact on residents' income and wealth because tourists' spending sometimes has little to do with resident earnings and employment. Therefore, travel expenditures are best viewed as merely the initial monetary activity that stimulates the production process and initiates economic impact.

TRJ Tourism Research Journal, Volume 1 (1), 2017 
Economic impact of tourism involves direct and indirect impacts (Frecthling, 1994; Stynes, 1997 in Kausar, 2010). The direct impact occurs as a direct consequence of travel activity in the area, which includes wages, salaries, taxes, and business receipts; whereas indirect impact incorporates the production changes resulting from various rounds of re-spending of tourism businesses'receipts in other backward-linked industries, e.g. industries supplying products and services to hotel (Stynes, 1997 in Kausar, 2010).

Lindberg and Johnson (1997) in Kausar (2010) said that while economic impacts are perceived generally as positive, social and environmental impacts of tourism are being perceived generally as negative. Economic benefits also tend to dominate decisions concerning tourism planning and development (Choy cited by Lindberg and Johnson, 1997 in Kausar, 2010). However, tourism can be a major agent of change in the social, political, and cultural system of a destination area - sometimes leading to social change or even social problems (Crandall, 1994 in Kausar, 2010). Therefore, understanding of non-economic impact of tourism is important and can be incorporated into policymaking process related to tourism (Lindberg and Johnson, 1997 in Kausar, 2010).

Social and economic benefits and costs are so intertwined and it is difficult to differentiate between the two, hence the term socio-economic impact. Crandall (1994) in Kausar (2010) stated that some of socio-economic impact of tourism include, i.e. changes in forms of employment, changes in land values and ownership, and improved standard of living. Socio-economic impact can then be defined as the changes in social fabric, which are influenced by economic impacts.

\section{Research Methodology \\ 1. Research Design}

This research is a mixed research that combines the approach of quantitative and qualitative research, namely quantitative qualitative descriptive research. Semi-structured interviews are conducted in order to obtain specific information from key informants either individually or in groups.

To avoid key informant bias in this research, triangulation of information was done towards key informants. Informants are determined based on the needs of research data, i.e. those who are considered competent with a comprehensive and adequate understanding of tourism development of Sembalun. Selected informants represent the government sector, business actors, religious/community leaders, and visitors. In addition, the focus group discussion was also conducted, which was carried out along with elements of the community including tourism managers, village officials and community leaders. In the context of gender, this forum is also attended by women and men.

Surveys are one of the methods that can be used in social impact assessment, such as changes in employment and improvement in living standards

TRJ Tourism Research Journal, Volume 1 (1), 2017 
(Crandall, 1994 in Kausar, 2010). Household surveys in this research used a questionnaire in order to obtain a standard answer so as to allow for quantification and comparison. Non-probability sampling technique was used in the survey. The respondents' targets are people aged 20 and older who are mature enough to provide answers to questions about their households. Furthermore, the type of non-probability sampling used is convenient sampling.

The research was conducted in Sembalun Sub-district, East Lombok Regency NTB consisting of the following activities: In-depth interviews were conducted on 28 October 2016 - 16 April 2017, focus group discussion was held on 28 October 2016 at Hotel Nusantara Sembalun in order to explore and capture the actual situation about the development of tourism in Sembalun, preparation and distribution of questionnaires on 23 February - 24 March 2017, and verification of the results of the questionnaire for the completion of results and discussion on 27 March - 17 April 2017.

\section{Research Instrument}

The Sustainable Livelihood Framework is an approach developed by the Overseas Development Institute (ODI, UK) used in this research to assess the impacts of tourism on people's livelihoods. Ashley (2000) in Kausar (2010) stated that assessing the impact of tourism on local communities is not sufficient if it only includes cost and benefit, such as profit and employment creation, but it must also include various indirect impacts, both positive and negative. It is therefore important to see how tourism creates an impact or contributes to the livelihoods of rural households, not only from an economic perspective, such as job creation and income. Another impact is how it affects other components such as rural infrastructure that contribute to meet the household needs or providing opportunities for starting a small business. In addition, tourism also has impacts in creating opportunities to improve skills, for example in hospitality or to learn a foreign language which is ultimately useful in improving the economy at this present time or in the future.

This is what is embedded in the Sustainable Livelihood Framework. This particular approach is chosen because it corresponds to a situation that is relevant to the rural community, where usually every household member undertakes various efforts in order to contribute to fulfilling one or more household needs.

The table below shows the working variables developed by Kausar (2010) for a survey on Borobudur based on the Sustainable Livelihood Framework. The same research variables were used in the survey conducted in Sembalun by adjusting it to rural tourism conditions in this area. Each variable represents a social or economic impact. 
Table 3. Working Variables Developed for Assessing Socio-economic Impacts Sustainable Livelihood Approach Working variables

Impacts of household asset

- Financial asset

- Physical asset

- Human resources

- Natural resources

- Social capital

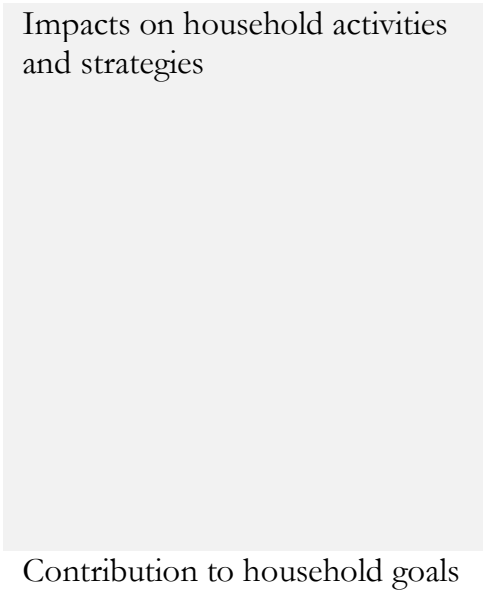

Participation
Economic Impacts

Increased income*

Increased land value*

Opportunity for starting small business (entrepreneurship opportunity)*

Tourism promotes assistance for local product development** Opportunity to engage in economic activities in heritage site (recreation park)* Position of tourism job (if any) relatives to other job (e.g. agriculture work), as a substitute or complementary job**

Improved well-being*

The type of income received from tourism related jobs. Does household recceives fixed/regular income from tourism jobs?**
Access to the heritage site (recreation park) for recreational purpose*
Opportunity for skill improvement*

Tourism impacts on the social and natural environment* Sense of pride toward the heritage site*

Sense of ownership toward the heritage site* Preservation of local culture* Changes in social relationships induced by tourism*

\section{Tourism impact on rural infrastructure development* Impact of tourism on improvement of public facilities*}

Opportunity to participate in forums or meetings on tourism development in the $\operatorname{area}^{* *}$

Note: *Presented in the questionnaire as a Likert scales questions (five scales). **Samples chose either Yes or No as answers.

Source: Questionnaire prepared by Kausar (2010) based on Ashley (2000), Crandall (1994), Novelli and Gebhardt (2007).

\section{The Study Setting}

Four of six villages in Sembalun Sub-district were selected for the survey, namely Sembalun Bumbung Village, Sembalun Lawang Village, Sembalun Village and Sajang Village. The total population in these four villages is 15.765 people 
(BPS, Kecamatan Sembalun dalam Angka, 2015) of which $52 \%$ are female and $48 \%$ male. The reason for the selection of these four villages is because one of the following criteria can be fulfilled by these four villages, namely (1) significant number of people with tourism-related jobs, (2) existence of tourism activity in the village, (3) the existence of a rural tourism-related industry (e.g. souvenirs), or (4) existence of a home industry that has been rooted in the livelihood of the village although it is not directly related to tourism. The two villages that were not selected for the survey are Bilok Petung Village and Sembalun Timba Gading Village. In Sembalun Timba Gading Village there is no tourist attraction, so its function is only to provide supports in the field of culinary.

Sample size was determined following the previous research by Kausar (2010) using a formula developed by Watson et al (1993: 360) for population with unknown parameters, as follows.

$$
n=\frac{4 \cdot Z \frac{1}{2} \cdot p(1-p)}{(\omega)^{2}}
$$

In this research, the number of sample $(n)$ is 120 ; the degree of success is expected to reach $90 \%$; the size of errors that can be tolerated is set at $6 \%$ for each side (between $5 \%$ to $10 \%$ is commonly used). $n$ is sample size; $Z \frac{1}{2}$ is confidence coefficient, where $\alpha$ represents sampling error; $\varrho$ is the degree of success expected from the sample; $(1-\varrho)$ is the degree of failure; $\omega=\mathrm{L}+\mathrm{R}$ is the number of error that can be tolerated from population in the left and right side of a normal distribution curve.

\section{Result and Discussion}

In 1997-1998 Sembalun's economy was destroyed by an outbreak of garlic diseases. At that time the main concern was the high intensity of chemical fertiliser which seriously affected the ecology. On the other hand there was an increase in security and criminal issues around Rinjani so that the number of tourist visits dropped dramatically. Due to the occurrence of these two incidents, people become aware about the important benefits of tourism and started to participate in tourism activities. Afterwards people held a discussion to find solutions towards the existing problems in Rinjani.

Tourism in Sembalun has been growing rapidly in the last three years. This can be seen by the increasing number of traders who ultimately improve the economic income of villagers. In addition, the profession as a guide and porter has become a permanent job. In Sembalun the tourism sector synergises with the agricultural sector. With the added value provided by tourism, strawberry farmers are able to meet the needs of their households and send their children to schools. 


\section{Survey of Socio-Economic Impacts on Livelihoods}

The survey was conducted in four out of six villages in Sembalun Subdistrict with a total of 120 respondents representing approximately $0,8 \%$ of the total population in these villages. Among 120 respondents, 62 respondents $(58 \%)$ were involved in the tourism-related jobs and 58 respondents $(42 \%)$ were not. In addition, since this research also seeked to see gender issues related to tourism development in Sembalun, 85 men (71\%) and 35 women (29\%) were selected as respondents.

The respondents selected in this survey are those aged 20 and older who are mature enough and able to provide answers to questions about households. The age of a total of 60 respondents $(50 \%)$ of the sample is between 30-49 years. At this age they are considered as established in work and mindset and in general they have family dependents. 82 respondents (68\%) work as farmers and 36 of 82 farmers have additional work related to tourism, namely working in agrotourism, as porters, guides, homestay managers, and parking attendants. More than $50 \%$ of respondents are high school graduates. In addition, $17 \%$ of respondents are college graduates.

Table 4. Respondents' Opinions on the Various Aspects of Livelihood Affected by Tourism

\begin{tabular}{|c|c|c|c|c|c|c|}
\hline No. & Statement & $\begin{array}{l}\text { Strongly } \\
\text { agree }\end{array}$ & Agree & Neutral & Disagree & $\begin{array}{l}\text { Strongly } \\
\text { disagree }\end{array}$ \\
\hline 1. & $\begin{array}{l}\text { Increased land value because of } \\
\text { tourism }\end{array}$ & $41,67 \%$ & $39,17 \%$ & $9,17 \%$ & $7,50 \%$ & $2,50 \%$ \\
\hline 2. & $\begin{array}{l}\text { Improvement of household } \\
\text { income }\end{array}$ & $25,83 \%$ & $37,50 \%$ & $26,67 \%$ & $5,83 \%$ & $4,17 \%$ \\
\hline 3. & $\begin{array}{l}\text { Opportunity for skills } \\
\text { improvement }\end{array}$ & $25 \%$ & $35 \%$ & $28,33 \%$ & $6,67 \%$ & $5 \%$ \\
\hline 4. & Conservation of local culture & $28,33 \%$ & $41,67 \%$ & $21,67 \%$ & $5,83 \%$ & $2,50 \%$ \\
\hline 5. & Sense of pride & $44,17 \%$ & $37,50 \%$ & $15 \%$ & $1,67 \%$ & $1,67 \%$ \\
\hline 6. & Sense of ownership & $27,50 \%$ & $55 \%$ & $13,33 \%$ & $2,50 \%$ & $1,67 \%$ \\
\hline 7. & $\begin{array}{l}\text { Tourism has positive impacts to } \\
\text { rural infrastructure } \\
\text { development }\end{array}$ & $23,33 \%$ & $45,83 \%$ & $23,33 \%$ & $5 \%$ & $2,50 \%$ \\
\hline 8. & $\begin{array}{l}\text { Tourism has positive impacts } \\
\text { on improvement of public } \\
\text { facilities }\end{array}$ & $21,67 \%$ & $45 \%$ & $23,33 \%$ & $8,33 \%$ & $1,67 \%$ \\
\hline 9. & Improvement of well-being & $19,17 \%$ & $49,17 \%$ & $23,33 \%$ & $7,50 \%$ & $0,83 \%$ \\
\hline 10. & $\begin{array}{l}\text { Tourism opens opportunities to } \\
\text { start small business }\end{array}$ & $21,67 \%$ & $51,67 \%$ & $19,17 \%$ & $5,83 \%$ & $0,83 \%$ \\
\hline 11. & $\begin{array}{l}\text { There are changes in social } \\
\text { relationships between residents }\end{array}$ & $6,67 \%$ & $52,50 \%$ & $28,33 \%$ & $9,17 \%$ & $3,33 \%$ \\
\hline
\end{tabular}


12. Decreasing access to recreation

$$
6,67 \%
$$

$13,33 \%$

$25 \%$

$35 \%$

$20 \%$

13. Decreasing opportunities to

$\begin{array}{rrrrr}4,17 \% & 10,83 \% & 37,50 \% & 33,33 \% & 14,17 \% \\ 5 \% & 10,83 \% & 34,17 \% & 35 \% & 15 \%\end{array}$

engage in economic activities in the recreation park*

14. Tourism has negative impacts

to the surrounding social natural environment

Note: $*$ indicates negative statement, thus $1=$ strongly agree, $2=$ agree, $3=$ neutral, $4=$ disagree, and $5=$ strongly disagree.

Source: Survey conducted by author

During an in-depth interview with the Head of Sembalun Sub-district, Usman, he stated that tourism development has a positive and negative impacts. According to him, there are more positive impacts in of that in Sembalun than the negative ones. This is also reflected in the results of research in Sembalun, where the sample states their positive perception on the tourism development in the village.

Table 5. Descriptive Statistics for the Fourteen Scale Items as Major Part of the Questionnaire

\begin{tabular}{|c|c|c|c|c|c|}
\hline No. & Statement & $\mathrm{N}$ & Min & Max & Mean \\
\hline 1. & Increased land value because of tourism & 120 & 1 & 5 & 4,10 \\
\hline 2. & Improvement of household income & 120 & 1 & 5 & 3,75 \\
\hline 3. & Opportunity for skills improvement & 120 & 1 & 5 & 3,68 \\
\hline 4. & Conservation of local culture & 120 & 1 & 5 & 3,88 \\
\hline 5. & Sense of pride & 120 & 1 & 5 & 4,21 \\
\hline 6. & Sense of ownership & 120 & 1 & 5 & 4,04 \\
\hline 7. & $\begin{array}{l}\text { Tourism has positive impacts to rural infrastructure } \\
\text { development }\end{array}$ & 120 & 1 & 5 & 3,83 \\
\hline 8. & $\begin{array}{l}\text { Tourism has positive impacts on improvement of } \\
\text { public facilities }\end{array}$ & 120 & 1 & 5 & 3,77 \\
\hline 9. & Improvement of well-being & 120 & 1 & 5 & 3,78 \\
\hline 10. & $\begin{array}{l}\text { Tourism opens opportunities to start small } \\
\text { business }\end{array}$ & 120 & 1 & 5 & 3,85 \\
\hline 11. & $\begin{array}{l}\text { There are changes in social relationships between } \\
\text { residents }\end{array}$ & 120 & 1 & 5 & 3,50 \\
\hline 12. & $\begin{array}{l}\text { Decreasing access to recreation park for } \\
\text { recreational purposes* }\end{array}$ & 120 & 1 & 5 & 3,48 \\
\hline 13. & $\begin{array}{l}\text { Decreasing opportunities to engage in economic } \\
\text { activities in the recreation park* }\end{array}$ & 120 & 1 & 5 & 3,43 \\
\hline 14. & $\begin{array}{l}\text { Tourism has negative impacts to the surrounding } \\
\text { social natural environment }\end{array}$ & 120 & 1 & 5 & 3,44 \\
\hline
\end{tabular}

Note: $\mathrm{N}=$ number of response

Source: Survey conducted by author 


\title{
2. Comparing the Results of Reseaches in Borobudur and Sembalun Based on the Approach of Sustainable Livelihood Framework
}

\author{
Impacts of household asset (financial, physical, human resources, natural resources, social \\ capital)
}

Borobudur

- The impacts of tourism to local economy are mostly still limited to generating local employment in the informal sectors, which has been posing a problem for the quality of tourism itself.

- Its impact on other sectors is limited to a few economic activities closely linked to tourism, i.e. tourism villages and souvenirs.

- It has not been impacting significantly on the opportunities to start small

businesses and to the provision of financial assistance or training for local product development

- The agricultural sector and food production cannot be promoted. Existing commodities (papaya, rambutan, oranges) are not introduced as typical products of Borobudur.

- Tourism cannot promote local products in Borobudur. In general, these products are imported from other regions, resulting in the leakage of the economy because the majority of the products sold are produced by other regions. It is caused, among others, because the community does not have agricultural land or limited land area.

- Limited linkages between tourism and other sectors in rural economies indicate an unbalanced distribution of tourism benefits across all existing economic activities
Sembalun

- Tourism development brings positive and negative impacts. However, the majority of respondents from public and private sector and local communities feel confident that more positive impacts are taking place in Sembalun compared to negative impacts.

- The most positive impacts perceived by the community are as follows:

- increase in land value due to tourism $(80,83 \%)$,

- opportunity to develop MSMEs $(74,95 \%)$,

- preservation of local culture $(70 \%)$,

- infrastructure development/village infrastructure facilities $(69,17 \%)$,

- increase of community welfare $(68,33 \%)$

- improvement of public facilities $(66,67 \%)$

- increase in household income $(63,33 \%)$

- opportunities to improve skills through training $(60 \%)$,

- positive changes in social relations among rural communities (59,17\%).

- People also feel proud to be part of the tourism village $(82,50 \%)$ and because Sembalun has become a tourism destination $(81,67 \%)$.

- Tourism is able to promote local products. This is supported by extensive land for production and an opportunity to gain financial support and capacity building.

- Local products from Sembalun are distributed to meet the needs of other tourism areas around North Lombok and West Lombok including Senggigi, even Bali.

- Despite the development of tourism, people do not feel that their access to tourism is difficult $(55 \%)$. 


\section{Impacts on household activities and strategies}

\section{Borobudur}

- Tourism has encouraged a shift in jobs based on agriculture to tourism, both in the form of trade and services.

- Some local people turn to tourism because they have no agricultural land and if any it is very limited.

- The challenges faced by local communities are:

1) Tourism-related jobs are informal without income stability,

2) There is competition with many people involved,

3) The scarcity of existing job opportunities so that people rely heavily on tourism revenues.
Sembalun

- The community in Sembalun began to engage in tourism activities after the destruction in the agricultural sector and security issues that were experienced by the climbers of Mount Rinjani.

- The results of the research indicate a positive perception of the local communities. Tourism is considered as a secondary sector and agricultural sector which remains the primary sector is not forgotten by the local communities. But, through tourism, the agricultural sector gets added value and diversification of products, such as agro-tourism.

- Only $28 \%$ of the sample stated that work related to tourism has replaced their previous work.

- Because of tourism the young generation has the option to remain in their village, thus preventing urbanisation

\section{Contribution to household goals (well-being, income)}

Borobudur

- Survey results indicate a positive perception of the impact of tourism. However, there is little positive impact for most local people in rural Borobudur.

- Tourism has not created a significant impact on the agricultural sector, where more than $40 \%$ of the workforce is involved.

- Tourism in Borobudur only slightly encourages the growth of other sectors in the local economy.

- There has been no significant impact on welfare, job creation and income. $43 \%$ of the sample has income below $R p 500,000$ (below Regional Minimum Wage of Rp 650,000 per month in 2010).
Sembalun

- The majority of samples confirm the increase of welfare $(68,33 \%)$ and household income $(63,33 \%)$.

- However, the income from $50 \%$ of the sample is still below the Regional Minimum Wage of East Lombok.

- Family income increases with the promotion of local products (MSMEs), such as processed food products and agricultural products as a result of tourism development. It also supports product diversification so people can continue to innovate and be competitive.

\section{Capacity of local communities to influence external policy environment (participation)}

\section{Borobudur}

- Tourism-related job has led to competition with many people involved in the sector.

- The participation of local communities in tourism development is voluntary and

\section{Sembalun}

In Sembalun there are many business groups operating individually, which tend to compete and bring potential conflicts in the future.

Thus, in 2016 the Tourism Forum called 
based on community ideas and motivations.

- The community has been conscious of having a bargaining position in dealing with other interested parties in Borobudur, so they work together in establishing cooperative in order to have an influence in the decision-making process and obtain alternative income other than agriculture.
"Geowisata Sembalun" was established, which consists of representatives from different organisations.

The local communities have realised that their involvement in the tourism devlopment is very important. Even in Sembalun Bumbung Village planning is prepared by the village government based on the inputs from the youth, such as for tourism supporting infrastructure development.

\section{E. Conclusion}

In the past, the Sembalun people rely on agriculture as their livelihood sources, but with the economic failures as well as the rising level of crime against tourists climbing Mount Rinjani, they began to move to pursue tourism as an alternative livelihood. This is supported by the great potentials possessed by Sembalun, especially because of its strategic location near Mount Rinjani, so that at least half of the tourists who climb the mountain also visit Sembalun. The scenic beauty of Sembalun is also complemented with the rich culture, easy accessibility to Sembalun, and adequate tourism amenities for the village level.

Although the villagers are engaged in the tourism sector now, but agriculture is not forsaken. In fact, agriculture and tourism in Sembalun support each other. Strawberry commodity has become one of the attractions, e.g. picking strawberries are tourists' great demand. In addition, Sembalun agricultural products are also supporting the tourism sector in other areas of Lombok Island, such as to meet the needs of hotels around Mataram, West Lombok and North Lombok. In general, farmers in Sembalun also have additional jobs in tourism, such as guide, porter, homestay manager, and others. Only $28 \%$ of the sample stated that tourism-related jobs have replaced their previous jobs.

Comparing between positive and negative impacts, respondents believe that the positive impact is still more than the negative impact (see table Table 4. Respondents' Opinions on the Various Aspects of Livelihood Affected by Tourism). Tourism improves financial support and training in building and promoting local products (MSMEs). In addition, tourism also creates a positive impact on increasing the value of land, cultural preservation, infrastructure development and public facilities. The local communities in Sembalun feel proud to be part in the development of tourism villages, and feel a positive change in social relations among villagers.

Regarding income, more than $50 \%$ of respondents have monthly income of less than Rp 1 million (around USD 77), which means it is still below the Regency Minimum Wage of East Lombok, which is Rp 1.488.525 in 2015 (BPS, Kabupaten Lombok Timur dalam Angka, 2016). According to the young 
entrepreneurs in the field of tourism, Armasih and Rozak, the figure chosen by the respondents in the questionnaire was only an estimate. In general, the income they earn is not fixed due to their informal work and also because the respondents have limitations in accumulating income due to their lack of knowledge in financial management. But apart from that, it could be that it is indeed a reality because based on the Statistical Office of Lombok Timur in 2016 the percentage of poor people in East Lombok is about 19\%, and the area has the second largest percentage of the poor people in NTB with approximately 219.665 people live below the poverty line.

The most common negative impact is on waste. This is regarding the fact that Sembalun itself does not have adequate supporting infrastructure. Waste problems also occur due to problem of management in Mount Rinjani, especially with the enactment of Government Regulation No 12 Year 2014 about Types and Tariffs of Non-Tax State Revenue, so that the Rinjani Trek Management Board (RTMB) that also managed the waste disposal. Currently the tasks of the stakeholders are unclear and they are throwing responsibilities to each other.

Women's involvement in tourism activities has not been maximised. Currently, women's representation in tourism governance is only $12 \%$. Compared to the role of women in the field of food processing MSMEs that strongly support the family economy, their role in tourism activities should still be improved, e.g. through capacity building training.

Factors that cause the positive impacts as mentioned above are (1) the natural beauty and cultural richness as a fascinating tourism attraction in Sembalun, (2) strategic and accessible location (about 2.5 hours from Mataram), (3) the young generation as the labor force who are eager to build their village, (4) support from village government as well as religious and community leaders, (5) support for capacity building, finance, marketing and promotion provided by the ministries and other institutions, (6) wide fertile land and low population density, and (7) economic carrying capacity is quite convenient. Through their engagement in the tourism, the young generation in Sembalun has the option to remain in their village, thus it also prevents the urbanisation.

Researches using the Sustainable Livelihood Framework conducted in both Borobudur and Sembalun were focused on assessing the impacts of tourism on community livelihoods. Thus, further research focuses on the economic impacts is needed which compares before and after the development of tourism, such as increased sales, job creation, increased employment, cost and benefit, etc. This needs to be done primarily to monitor the impacts of tourism in the future, especially to find out the increase of income of Sembalun society which is mostly under the Regional Minimum Wage whereas the majority of sample stated that there is an increase of household income and welfare. 
Socio-Economic Impacts of Tourism Development in Rural Area of Sembalun East Lombok West Nusa

\section{F. Acknowlegement}

I would like to show my gratitude to my main advisors in the Graduate School Trisakti Institute of Tourism, Djoko Sudibyo, SE, MM, PhD and Ir. Henky Hermantoro, MURP/MPA for their guidance, supervision and support whilst undertaking this research. I also would like to convey my special thanks to Dr. Himawan Brahmantyo, SE, MM and Dr. Ir. Adhi Trirachmadi Mumin, MM who supported me through their critical questions and comments to improve my research. Furthermore, I am very bonoured to have the support from Dr. Devi Roza Krisnandhi Kausar who has shared the experience of her dissertation research in Borobudur which I replicated for my research in Sembalun. This research would not have been made possible without the support of the management and colleagues in the Sustainable Regional Economic Growth dan Investment Program (SREGIP) implemented by Bappenas and the Deutsche Gesellschaft für Internationale Zusammenarbeit (GIZ) GmbH, especially Jonas Naguib, Dr. Prayitno Basuki, and Rahman Dayani, MM. I am also very thankful to the local communities in Sembalun who always gave me warm welcome and was willing to participate in the surveys and focus group discussions. In particular, I would like to thank Armasih, Abdul Rozak, and Amir Riis who belped me in the interviews, surveys and data collection. Last but not least, I am immensely grateful to my beloved family for their everlasting supports and prayers for me.

\section{REFERENCES}

Ashley, C. (2000). The Impacts of Tourism on Rural Livelihoods: Namibia's Experience. Working paper 128. London: Overseas Development Institute

Asker, S, Boronyak, L, Carrard, N, dan Paddon, M. (2010). Effective Community Based Tourism. A Best Practice Manual. Singapore: Sustainable Tourism Cooperative Research

Assante, L.M., et al. (2007). An empirical assessment of residents' attitudes for sustainable tourism development: a case study of $\mathrm{O}^{\prime} a h u$. Hawai'i. Journal of Sustainability and Green Business

Balai Taman Nasional Gunung Rinjani. (2015). Statistik Balai Taman Nasional Gunung Rinjani Tabun 2015. Jakarta : Kementerian Lingkungan Hidup dan Kehutanan

Firnandy. (n.d.). Studi Profil Pekerja di Sektor Informal dan Arah Kebijakan ke Depan. Jakarta : Direktorat Ketenagakerjaan dan Analisis Ekonomi Bappenas

Global Sustainable Tourism Council (GSTC). (2013). Global Sustainable Tourism Criteria. Global Sustainable Tourism Criteria for Destinations (Version 1.0 Dec. 2013). downloaded from www.gstcouncil.org/resource-center/gstccriteria.htm

Hermantoro. H. (2015). Kepariwisataan. Destinasi Pariwisata. dan Produk Wisata. Depok: Aditri. page 73-94

TRJ Tourism Research Journal, Volume 1 (1), 2017 
Socio-Economic Impacts of Tourism Development in Rural Area of Sembalun East Lombok West Nusa

Inskeep, E. (1991). Tourism Planning: An Integrated and Sustainable Development Approach. New York.

Kausar, D. (2010). Socio-Economic Impact of Tourism on a World Heritage Site (WHS): Case Study of Rural Borobudur, Indonesia. Nagoya University

Nuryanti, W. (1993). Concept. Perspective and Challenges. makalah bagian dari Laporan Konferensi Internasional mengenai Pariwisata Budaya. Yogyakarta: Gadjah Mada University Press. Page 2-3

Rahman, D. (2016). Laporan Konsultan Pengembangan Desa Wisata Hijau di Sembalun. Mataram: GIZ

Saufi, et al. (2013). Inbibitors to Host Community Participation in Sustainable Tourism Development in Developing Countries. Journal of Sustainable Tourism

Sahidu, A.M. (2012). Strategi Nafkah Rumah Tangga Petani Sasak Persawahan dan Nelayan Sasak Pesisir di Lombok Timur. Journal Masyarakat. Kebudayaan dan Politik Volume 25 No. 4. Oktober-Desember 2012. Surabaya : Departemen Kelautan FPIK Universitas Airlangga.

Stynes, D.J. (1997). Economic Impacts of Tourism. downloaded from http://www.msu.edu/course/prr/840/econimpact/pdf/ecimpvol1.pdf.

Suarthana, I.K., et al (2015). Exploring the Community Participation. Tourism Village. and Social-Economic to Environment Impact (Case Study: Pentingsari Village. Yogyakarta). International Journal of Business and Management Invention

Susyanti, D.W. (2013). Potensi Desa Melalui Pariwisata Perdesaan. Jurnal Ekonomi dan Bisnis. Vol 12. No. 1. Juni 2013. page 33-36

Thailand Community Based Tourism Institute. (2013). Innovating CBT in ASEAN: Current Directions and New Horizons

Tourism Resource Consultant. (2005). Gunung Rinjani National Park: Rinjani Trek Ecotourism Programme. End of Transition Phase Report. NZAID

UNEP and UNWTO. (2005). Making Tourism More Sustainable. A Guide for Policy Makers

UNWTO STEP Foundation. (2011). Introduction to Sustainable Tourism. Seoul: UNWTO STEP Foundation

van Breugel, L. (2013). Community-based tourism: Local participation and perceived impacts. Nijmegen: Faculty of Social Sciences Radboud University Nijmegen

World Travel and Tourism Council (2016). Benchmarking Report on Indonesia 2015.

TRJ Tourism Research Journal, Volume 1 (1), 2017 